International Journal of Agriculture, Environment and Bioresearch

Vol. 06, No. 05; 2021

ISSN: $2456-8643$

\title{
REACTION OF BREAD WHEAT ADVANCED LINES TO KARNAL BUNT ARTIFICIAL INOCULATION DURING THE 2015-2016 SEASON
}

\begin{abstract}
FUENTES-DAVILA Guillermo, PRAKASH-SINGH Ravi, ROSAS-JAUREGUI Ivon Alejandra, AYONIBARRA Carlos Antonio, TORRES-CRUZ Maria Monserrat, FELIX-VALENCIA Pedro and FELIXFUENTES Jose Luis
\end{abstract}

INIFAP, CAMPO EXPERIMENTAL NORMAN E. BORLAUG, Apdo. Postal 155, km 12 Norman E. Borlaug, entre 800 y 900, Valle del Yaqui, Cd. Obregón, Sonora, México CP 85000.2CIMMYT INT.,km 45 Carret. MéxicoVeracruz, El Batán, Texcoco, Edo. de México CP 56130

https://doi.org/10.35410/IJAEB.2021.5667

\begin{abstract}
One thousand and ninety two bread wheat advanced lines were evaluated for their reaction to Tilletiaindica during the crop season 2015-2016. Sowing dates were November 12 and 19, 2015, using $8 \mathrm{~g}$ of seed for a row 0.7 mlong on a bed with two rows. Inoculations in the field were performed by injecting $1 \mathrm{~mL}$ of an allantoidsporidial suspension $(10,000 / \mathrm{mL})$ during the boot stage in 5 spikes per line. The percentage of infection was determined by counting healthy and infected grains. The range of infection in the first date was $0-75.18$ with a mean of $17.89 \%$, while in the second date it was $0-83.45 \%$ with a mean of $21.45 \%$. The range of infection of the two dates was $0.18-70.64 \%$ with a mean of $19.67 \%$.Thirty seven lines showed a percentage of infection equal or below $2.5 \%$ in both dates, and out of those lines, the following four showed less than

0.5\%:SAUAL/3/SW89.3064//CMH82.17/SERI/4/SAUAL/5/PBW343*2/KUKUNA*2//FRTL/PI FED/6/SAUAL/KRONSTADF2004,MEX94.27.1.20/3/SOKOLL//ATTILA/3*BCN/5/CHRZ//B OW/CROW/3/WBLL1/4/CROC_1/AE.SQUARROSA(213)//PGO,TACUPETOF2001/6/CNDO/ R143//ENTE/MEXI_2/3/AEGILOPSSQUARROSA(TAUS)/4/WEAVER/5/PASTOR/7/ROLF0 7/8/KACHU\#1/KIRITATI/KACHU, and BABAX/LR42//BABAX/3/ER2000/6/POTCH93/4/MILAN/KAUZ//PRINIA/3/BAV92/5/MILA N/KAUZ//PRINIA/3/BAV92. Lines with the highest percentage of infection were: TUKURU//BAV92/RAYON/3/WBLL1*2/BRAMBLING/8/TACUPETOF2001/6/CNDO/R143/ /ENTE/MEXI_2/3/AEGILOPSSQUARROSA(TAUS)/4/WEAVER/5/PASTOR/7/ROLF07/9/T UKURU//BAV92/RAYON*2/3/JUCHI $\quad$ with $83.45 \quad$ and TACUPETOF2001/6/CNDO/R143//ENTE/MEXI_2/3/AEGILOPSSQUARROSA(TAUS)/4/WE AVER/5/PASTOR/7/ROLF07*2/8/SUP152/MUU with 83.10\%in the second date. The average of the three highest levels of infection of the susceptible checkwas $100 \%$..
\end{abstract}

Keywords: Bread wheat, Triticumaestivum, bread wheat, karnal bunt partial bunt, Tilletiaindica.

\section{INTRODUCTION}

Karnal bunt or partial bunt of wheat caused by the fungusTilletiaindicaMitra (syn. NeovossiaindicaMundkur), affects bread wheat (TriticumaestivumL.) (Mitra, 1931), durum wheat(T. turgidumL.) and triticale(X TriticosecaleWittmack) (Agarwal et al., 1977). The diseasehas been reported from India (Mitra, 1931), Mexico (Duran, 1972), Pakistan (Munjal, 
Vol. 06, No. 05; 2021

ISSN: $2456-8643$

1975), Nepal (Singh et al., 1989), Brazil (Da Luz et al., 1993), The United States of America (APHIS, 1996), Iran (Torarbiet al., 1996), the Republic of South Africa (Crouset al., 2001), and Afghanistan (CIMMYT, 2011).It is common thatthe fungus affects partially some grains in a spike, and not all the spikes are affected in a plant (Bediet al., 1949) (Fig. 1), butin some occasions, grains may be totally destroyed; although the fungus may penetrate the embryo, it is not necessarily lethal (Chonaet al., 1961; Mitra, 1935). Partially infected grains may produce healthy plants, although there are reports that indicate that the percentage of germination decreases depending on the level of infection of the grain (Bansal et al., 1984; Rai and Singh, 1978; Singh, 1980), and that severely affected seed lose viability or show abnormal germination (Rai and Singh, 1978);Fuentes-Dávilaet al., 2013 reported that seed with the greatest infection, but with the embryo intact, produced the highest number of tillers.

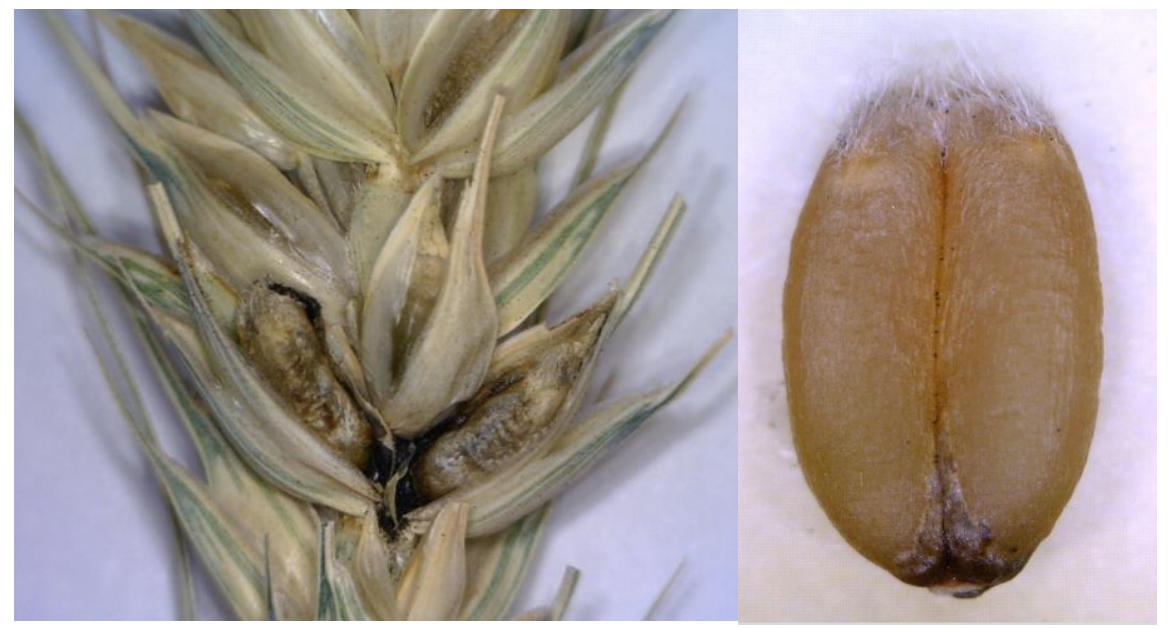

Figure 1. Wheat spike with infected grains with Tilletia indica. The grain shows a characteristic lesion caused by the pathogen.

Since teliospores of the fungus are resistant to physical and chemical factors (Krishna and Singh, 1982; Zhanget al., 1984; Smilanicket al., 1985, 1988), control of this pathogen is difficult; however, chemical control can be accomplished by spraying fungicides during flowering (Fuentes-Dávilaet al., 2005, 2016, 2018c; Salazar-Huerta et al., 1997). This measure would not beeconomically feasible where quarantine of phytosanitary regulations do not allow tolerance levels for seed production (SARH, 1987).Within a disease management scheme, the use of resistant wheat cultivars is the best control option, which would also contribute to reduce the possibilities of introduction of the disease into other areas where karnal bunt has not been established. The reaction to karnal bunt inoculation of several species of Triticum have been evaluated since the 1940's (Bediet al., 1949; Singh et al., 1986; 1988).Triticumaestivumis the species most affected by the disease; under artificial inoculation some lines may show more than 50\% infected grain (Fuentes-Dávilaet al., 1992; 1993; 2018a; 2019; 2020); therefore, it is important to keep evaluating the new advanced lines and wheat cultivars. The objective of this 
Vol. 06, No. 05; 2021

ISSN: $2456-8643$

work was to evaluate the reaction of one thousand and ninety twoadvanced bread wheat lines to inoculation withTilletiaindica in the field.

\section{MATERIALS AND METHODS}

One thousand and ninety two advanced bread wheat lines were evaluated for their reaction to Tilletiaindica, artificially inoculated in the field during the crop season fall-winter 2015-2016, at the Norman E. Borlaug Experimental Station in the Yaqui Valley, Sonora, Mexico, located in block 910 (27 $22^{\prime} 04.64^{\prime \prime}$ latitude north and 109 55'28.26" longitude west, 37 masl). The region has a warm climate [BW (h)] and extreme heat according to Koppen's classification modified by García (1988). Sowing dates were November 12 and 19,2015, using $8 \mathrm{~g}$ of seed for a row $0.7 \mathrm{~m}$ long on a bed with two rows in a clay soil with $\mathrm{pH}$ 7.8.For the agronomic management, INIFAP's technical recommendations were followed (Figueroa-Lópezet al., 2011). The inoculum was prepared by the isolation of teliospores from infected grains after shaking them in a water+tween solution, followed by centrifugation in $0.5 \%$ sodium hypochlorite, and plating on $2 \%$ water-agar Petri plates. After teliospore germination, fungal colonies were transferred and multiplied on potato-dextrose-agar. Inoculations were performed by injecting $1 \mathrm{~mL}$ of an allantoidsporidial suspension $(10,000 / \mathrm{mL})$ during the boot stage in five spikes from each line (Fig. 2). The use of an automatic mist spray-irrigation system five times a day for 20 min each time, provided high humidity in the area (Fig. 3).In order to protect the inoculated plants from bird damage, a plastic anti-bird net system was installed covering completely the experimental plots. Inoculations started on January 4 and ended on March 23, 2016, for a total of 33 inoculation dates. Inoculated spikes were collected in paper bags and threshed by hand, then, the counting of healthy and infected grains was done visually to determine the percentage of infection. The experimental germplasm originated from the joint project between the Global Wheat Program of the International Maize and Wheat Improvement Center (CIMMYT) and the National Institute for Forestry, Agriculture and Livestock Research in Mexico (INIFAP).

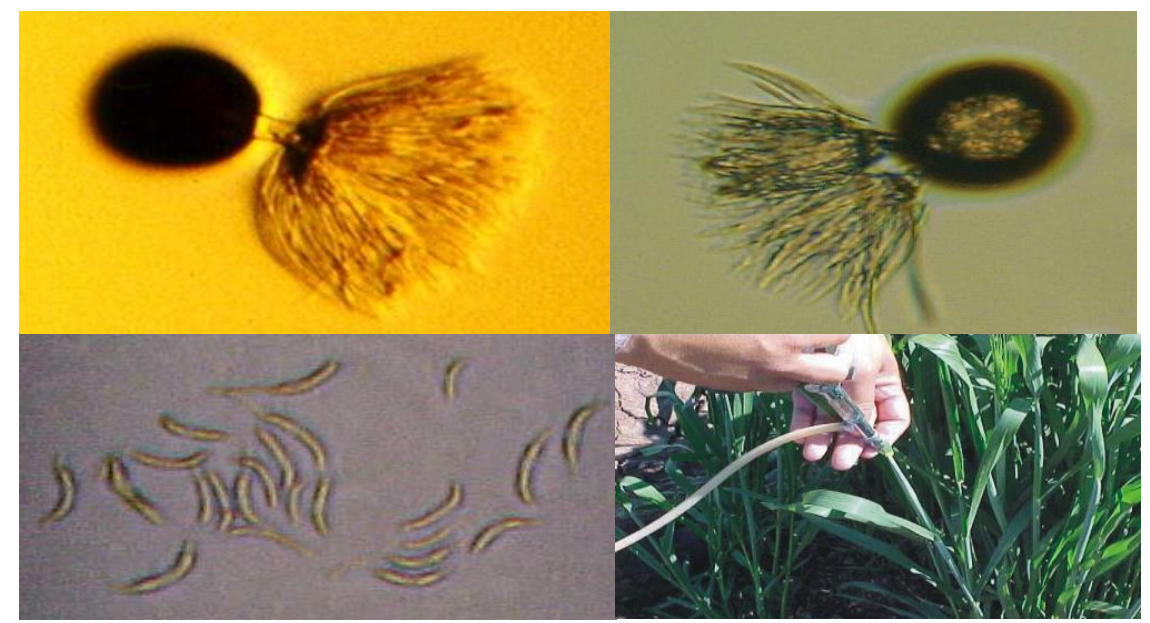

Figure 2. Teliosporegermination, producción of primary and secondary sporidia, and inoculation by injection during the boots tage of the wheat plant. 
Vol. 06, No. 05; 2021

ISSN: $2456-8643$

\section{RESULTS AND DISCUSSION}

The range of the percentage of infection of the advanced lines in the first date was $0-75.18 \%$ with a mean of $17.89 \%$; the infection categories in this date were: 25 lines did not show any infected grains, 66 fell in the $0.1-2.5 \%$ category, 63 in the 2.6-5.0\%, 165 in the 5.1-10.0\%, 592 in the $10.1-30.0 \%$ category, and 181 showed an infection percentage greater than $30.0 \%$. In this date, lines with less than $10 \%$ comprise $29.21 \%$ of the group which would offer an acceptable reaction to the inoculation with Tilletiaindica, the causal agent of the disease.

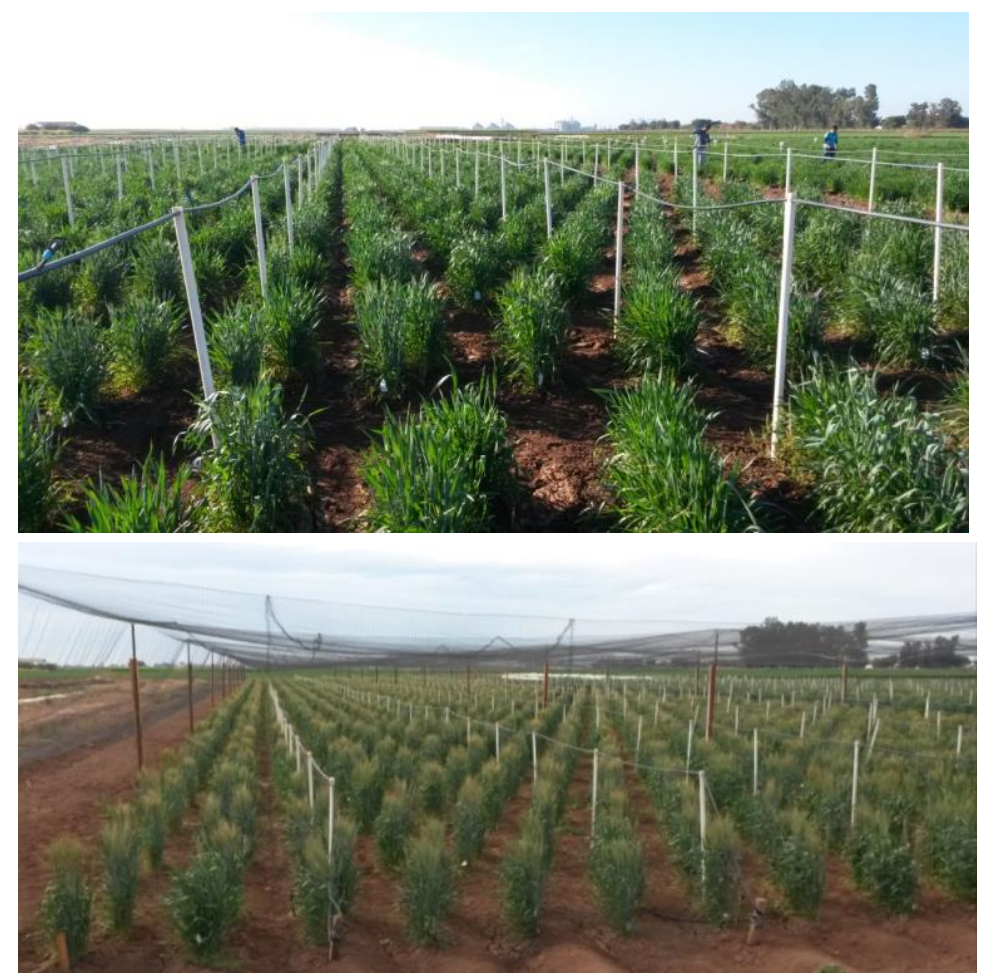

Figure 3. Mist-irrigation and anti-bird net in the experimental area, where bread wheat germplasmise valuated for their reaction to artificial inoculation with Tilletia indica.

The range of the percentage of infection of the advanced lines in the second date was $0-83.45 \%$ with a mean of $21.45 \%$; the infection categories in this date were: 23 lines did not show any infected grains, 37 fell in the $0.1-2.5 \%$ category, 74 in the $2.6-5.0 \%, 147$ in the $5.1-10.0 \%, 532$ in the 10.1-30.0\% category, and 279 showed an infection percentage greater than $30.0 \%$. In this date, lines with less than $10 \%$ comprise $25.73 \%$ very similar to the first date.In the overall results (mean of the two dates),65lines fell into the $0.1-2.5 \%$ infection category (37 lines had less than $2.5 \%$ infection in both dates), 67 within 2.6-5.0\%, 156 within 5.1-10.0\%, 586 within 10.1-30\%, and 218 with more than $30 \%$ infection (Fig. 4).Out of the 37 lines that had less than $2.5 \%$ 
infection in both dates, there were 10 lines that had less than $1.0 \%$ infection in both dates and 4 with less than $0.5 \%$ (Table 1).The range of infection of the susceptible check KBSUS was $69.81 \%$ onJanuary 27, 2016, to $100 \%$ on February 4, 8, 15, 16, and 29, and on March 2, 4, 7, 11, and 23 , with a mean of $92.53 \%$.The mean of the three highest percentage of infection of the susceptible check KBSUS was $100 \%$.

Since the late 80's and beginning of the 90's, in the Wheat Program of CIMMYT, the testing of experimental germplasm, introductions and Triticum species, high levels of resistance were detected not only in durum and triticale, but also in several Aegilops spp. (Warhamet al., 1986; Rajaramet al., 1991). Therefore, interspecific hybrids between Triticumturgidum xTriticumtauschii(Coss.) Schmalh. (syn. AegilopssquarrosaL.) were made since 1989 with the objective to incorporate resistance into bread wheat from the best synthetic hexaploids with good agronomic characteristics and cytogenetic stability (Villarealet al., 1995; Mujeeb-Kaziet al., 2006). Synthetic hexaploid wheats (SHW) are products of crosses involving tetraploid cultivars (Triticumturgidum, 2n=28, AABB) and diploid goat grass [AegilopstauschiiCoss. (syn. Aegilopssquarrosa, Triticum

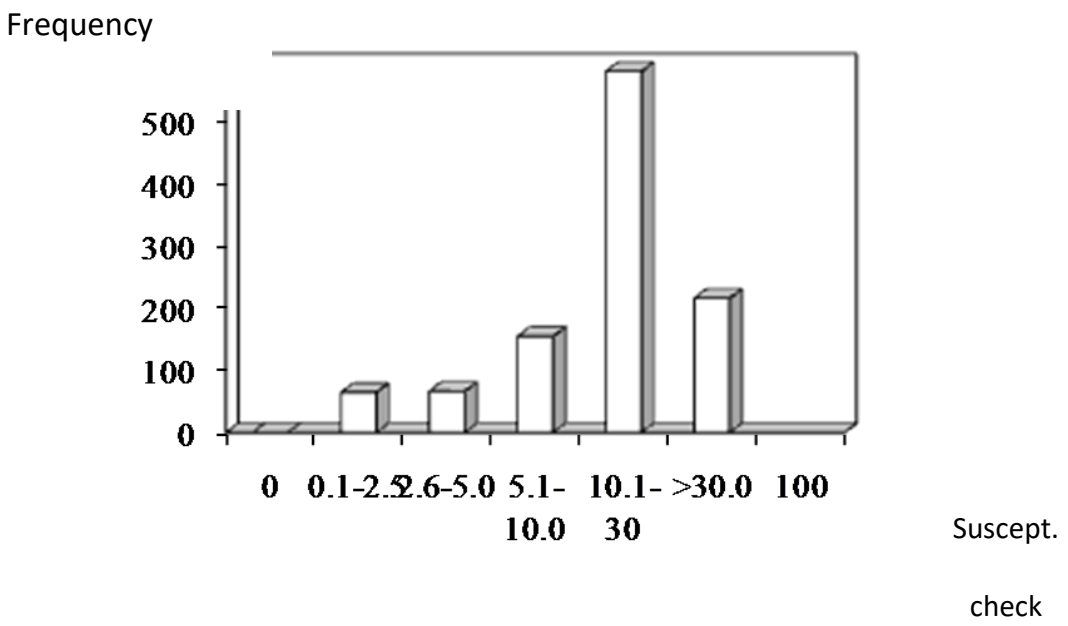

Infection categories (\%)

Figure 4. Karnal bunt infection categories (\%) for 1,092 bread wheat advanced lines artificially inoculated in the field in two dates during the 2015-2016 crop season, at the Norman E. Borlaug Experimental Station in the Yaqui Valley, Sonora, Mexico. The average of the three highest scores of infection of the susceptible check KBSUS was $100 \%$.

tauschii], 2n=14, DD), followed by chromosome doubling of $\mathrm{F}_{1}$ hybrids (Plamenov and Spetsov, 2011). They are genomically amphidiploids $(2 n=42$, AABBDD), combining the genomes of their 
parents. SHW exhibit resistance to some biotic factors, mainly fungi and insects, and may serve as valuable resources in wheat breeding. They can be involved in backcrosses with elite bread wheat cultivars to produce lines with superior quality, disease resistance and yield. Out of the 1,092 lines subject of the present evaluation, $22.06 \%$ carry in their pedigree a synthetic with the potential to be a contributor for the resistance to karnal bunt of a particular bread wheat line. In the case of CROC_1/AEGILOPS SQUARROSA(224) with 39 lines, only $12.8 \%$ of those lines were in the resistant category $0.1-5.0 \%$ (Fuentes-Dávila and Rajaram, 1994); for CROC_1/AE.SQUARROSA(213) with 39 lines, $15.4 \%$ were resistant; for CROC_1/AE.SQUARROSA(205) with 23 lines, 4.3\% were resistant; for ALTAR84/AE.SQUARROSA(221) with 8 lines, $12.5 \%$ were resistant; for ALTAR84/AE.SQUARROSA(205) with 9 lines, 22.2\% were resistant; for AE.SQUARROSA(TAUS) with 106 lines, $15.1 \%$ were resistant; for CHEN/AE.SQUARROSA(TAUS) with 4 lines, $25 \%$ were resistant. There were no resistant lines for AE.SQUARROSA(372), AE.SQUARROSA(409), and AE.SQUARROSA(498.). Other evaluations of elite bread wheat lines and synthetic hexaploid wheat derivatives like CROC_1/Ae. tauschii (205)//KAUZ/3/Attila have shown excellent resistance where the line did not show any infected grains; other lines with similar pedigree had between 0.1 to $2.5 \%$ (Fuentes-Dávila and Singh, 2006).In the case of the resistant line to karnal bunt MUNAL\#1(Fuentes-Dávilaet al., 2014) which is used routinely as check as well as in combination with other lines (Fuentes-Dávilaet al., 2018b), out of 37 lines with MUNAL\#1 in their pedigree, $8.1 \%$ showed resistance to the disease. In this group of 1,092 advanced bread wheat lines evaluated during the crop season 2015-2016, there were 132 which must be evaluated in the following season in order to verify their resistance shown to Tilletiaindica, since they may be prospects for commercial release, or at least be part of the progenitors used in bread wheat breeding programs.

Table 1. Bread wheat advanced lines that were artificially inoculated in the field with Tilletia indica, and showed less than $1 \%$ infection in two dates, during the cropseason 20215-2016, at the Norman E. Borlaug Experimental Station in the Yaqui Valley, Sonora, Mexico.

\begin{tabular}{|cl|}
\hline No. & \multicolumn{1}{c|}{ Pedigree and selectionhistory } \\
\hline \multicolumn{1}{|c|}{ Lines with less than 0.5\% } \\
\hline 1 & $\begin{array}{l}\text { SAUAL/3/SW89.3064//CMH82.17/SERI/4/SAUAL/5/PBW343*2/KUKUNA*2//FRTL/PIFED/6/ } \\
\text { SAUAL/KRONSTAD F2004 } \\
\end{array}$ \\
& CMSS11Y01091T-099TOPM-099Y-099M-099NJ-099NJ-16WGY-0B \\
2 & $\begin{array}{l}\text { MEX94.27.1.20/3/SOKOLL//ATTILA/3*BCN/5/CHRZ//BOW/CROW/3/WBLL1/4/CROC_1/AE. } \\
\text { SQUARROSA (213)//PGO }\end{array}$ \\
& CMSA11Y00402S-099Y-099M-099NJ-099NJ-18WGY-0B \\
3 & TACUPETOF2001/6/CNDO/R143//ENTE/MEXI_2/3/AEGILOPSSQUARROSA(TAUS)
\end{tabular}


International Journal of Agriculture, Environment and Bioresearch

Vol. 06, No. 05; 2021

ISSN: 2456-8643

/4/WEAVER/5/PASTOR/7/ROLF07/8/KACHU \#1/KIRITATI/KACHU

CMSS11B00310S-099M-099NJ-099NJ-9RGY-0B

4 BABAX/LR42//BABAX/3/ER2000/6/POTCH

93/4/MILAN/KAUZ//PRINIA/3/BAV92/5/MILAN/KAUZ//PRINIA/3/BAV92

CMSA11Y00305S-099Y-099M-099NJ-099NJ-1RGY-0B

Lines with less than $1 \%$

1 SEHER 06/3/PBW343*2/KUKUNA//TECUE \# 1

CMSS11Y00430S-099Y-099M-099NJ-099NJ-10WGY-0B

2 WBLL1*2/4/YACO/PBW65/3/KAUZ*2/TRAP//KAUZ/5/SAUAL/6/2*KINGBIRD

\#1//INQALAB 91*2/TUKURU

CMSS11Y00822T-099TOPM-099Y-099M-099NJ-099NJ-8WGY-0B

3 UP2338*2/4/SNI/TRAP\#1/3/KAUZ*2/TRAP//KAUZ/5/MILAN/KAUZ//CHIL/CHUM18/6/UP23 $38 * 2 / 4 / \mathrm{SNI} / \mathrm{TRAP} \# 1 / 3 / \mathrm{KAUZ} * 2 / \mathrm{TRAP} / / \mathrm{KAUZ} * 2 / 7 / \mathrm{PBW} 343 * 2 / \mathrm{KUKUNA} * 2 / / \mathrm{FRTL} / \mathrm{PIFED}$

CMSS11Y00993T-099TOPM-099Y-099M-099NJ-099NJ-25WGY-0B

4 SAUAL/3/SW89.3064//CMH82.17/SERI/4/SAUAL/5/PBW343*2/KUKUNA*2//FRTL/PIFED/6/ SAUAL/KRONSTAD F2004

CMSS11Y01091T-099TOPM-099Y-099M-099NJ-099NJ-25WGY-0B

5 MUNAL \#1/3/ATTILA*2/PBW65//MURGA

CMSS11B00006S-099M-0SY-9M-0WGY

6 WBLL1/3/STAR//KAUZ/STAR/4/BAV92/RAYON/5/TRAP\#1/BOW/3/VEE/PJN//2*TUI/4/BAV 92/RAYON/6/WAXWING/KIRITATI*2/3/C80.1/3*BATAVIA//2*WBLL1/7/PBW65/2*PASTO R//TACUPETOF2001*2/BRAMBLING/3/TACUPETO F2001*2/

BRAMBLING

CMSS11B00716T-099TOPY-099M-099NJ-099NJ-35WGY-0B

7 ATTILA*2/PBW65//MUU\#1/3/FRANCOLIN\#1/4/ATTILA*2/PBW65*2//KACHU/5/ ATTILA*2/PBW65//MUU \#1/3/FRANCOLIN\#1

CMSS11B00899T-099TOPY-099M-099NJ-099NJ-13WGY-0B

8 KACHU\#1/6/NG8201/KAUZ/4/SHA7//PRL/VEE\#6/3/FASAN/5/MILAN/KAUZ/7/KACHU/8/KZ A//WH 542/2*PASTOR/3/BACEU \#1/9/KACHU \#1/KIRITATI//KACHU 
International Journal of Agriculture, Environment and Bioresearch

Vol. 06, No. 05; 2021

ISSN: $2456-8643$

CMSS11B00916T-099TOPY-099M-099NJ-099NJ-2WGY-0B

9 PASTOR/3/URES/JUN//KAUZ/4/WBLL1/5/GKARON/AGSECO7846//2180/4/2*

MILAN/KAUZ//PRINIA/3/BAV92

CMSA11Y00276S-099Y-099M-099NJ-099NJ-13WGY-0B

10

BAV92//IRENA/KAUZ/3/HUITES/4/FN/2*PASTOR/5/BAV92//IRENA/KAUZ/3/HUITES/8/TA CUPETO F2001/6/CNDO/R143//ENTE/MEXI_2/3/AEGILOPS SQUARROSA (TAUS)/4/WEAVER/5/PASTOR/7/ROLF07/9/BAV92//IRENA/KAUZ/3/HUITES*2/4/GONDO/ TNMU

CMSS11Y01014T-099TOPM-099Y-099M-099NJ-099NJ-3RGY-0B

\section{CONCLUSION}

The range of the mean percentage of infection of one thousand and ninety two advanced bread wheat linesevaluated for their reaction to karnal bunt artificial inoculation in two sowing dates, during the crop season fall-winter 2015-2016, was $0.18-70.64 \%$ with a mean of $19.67 \%$. There were 4 lines that in both dates consistently showed a percentage of infection below $0.5 \%$ : SAUAL

/3/SW89.3064//CMH82.17/SERI/4/SAUAL/5/PBW343*2/KUKUNA*2//FRTL/PIFED/6/SAUA L/KRONSTADF2004, MEX94.27.1.20/3/SOKOLL//ATTILA/3*BCN/5/CHRZ//BOW/CROW /3/WBLL1/4/CROC_1/AE.SQUARROSA(213)//PGO, TACUPETOF2001/6/CNDO/R143// ENTE/MEXI_2/3/AEGILOPSSQUARROSA(TAUS)/4/WEAVER/5/PASTOR/7/ROLF07/8/

KACHU\#1/KIRITATI/KACHU, and BABAX/LR42//BABAX/3/ER2000/6/POTCH93/4/ MILAN/KAUZ//PRINIA/3/BAV92/5/MILAN/KAUZ//PRINIA/3/BAV92; and 33 below $2.5 \%$. Lines with the highest percentage of infection were: TUKURU//BAV92/RAYON/3/WBLL1*2/ BRAMBLING/8/TACUPETOF2001/6/CNDO/R143//ENTE/MEXI_2/3/AEGILOPS

SQUARROSA(TAUS)/4/WEAVER/5/PASTOR/7/ROLF07/9/TUKURU//BAV92/RAYON*2 /3/JUCHI with 83.45 and TACUPETOF2001/6/CNDO/R143//ENTE/MEXI_2/3/AEGILOPS SQUARROSA(TAUS)/4/WEAVER/5/PASTOR/7/ ROLF07*2/8/SUP152/MUU with 83.10\% in the second date. The average of the three highest levels of infection of the susceptible check was $100 \%$.

\section{REFERENCES}

Agarwal VK, Verma HS, and Khetarpal RK. 1977. Occurrence of partial bunt on triticale. PlantProt. Bull. 25:210-211.

APHIS. 1996. Karnal bunt: situation report update (March 29). USDA-APAHIS, Plant Protectionand Quarantine (http://www.aphis.usda.gov/oa/bunt).

Bansal R, Singh DV, and Joshi LM. 1984. Effect of Karnal bunt pathogen [Neovossiaindica (Mitra) Mundkur] on weight and viability of wheat seed. Indian J. Agric. Sci. 54:663-666.

Bedi SKS, Sikka MR, and Mundkur BB. 1949. Transmission of wheat bunt due to Neovossiaindica (Mitra) Mundkur. Indian Phytopathol. 2:20-26. 
Vol. 06, No. 05; 2021

ISSN: $2456-8643$

Chona BL, Munjal RL, and Adlakha KL. 1961. A method for screening wheat plants forresistance to Neovossiaindica. Indian Phytopathol. 14:99-101.

CIMMYT (Centro Internacional de Mejoramiento de Maíz y Trigo). 2011. Training to beat karnal bunt in Afghanistan. http://blog.cimmyt.org/tag/karnal-bunt/. Accessed March 1, 2014.

Crous PW, Van Jaarsveld AB, Castlebury LA, Carris LM, Frederick RD, and Pretorius ZA. 2001.

Karnal bunt of wheat newly reported from the African continent. Plant Disease 85:561.

Durán R. 1972. Further aspects of teliospore germination in North American smut fungi. II. Can.J. Bot. 50:2569-2573.

Da Luz WC, Mendes MAS, Ferreira MASV, andUrben AF. 1993. Tilletiaindica on wheat in the south of the state of Rio Grande do Sul, Brazil and measures for eradication. Fitopatologia Brasileira 18:S329.

Figueroa-López P, Fuentes-Dávila G, Cortés-Jiménez JM, Tamayo-Esquer LM, Félix-Valencia P, Ortiz-Enríquez E, Armenta-Cárdenas I, Valenzuela-Herrera V, Chávez-Villalba G. y FélixFuentes JL. 2011. Guía para producir trigo en el sur de Sonora. Folleto para productores No. 39. INIFAP-CIRNO, Campo Experimental Norman E. Borlaug. Cd. Obregón, Sonora, México. 63 p. Fuentes-Dávila G, Félix-Valencia P, Ayón-Ibarra CA, Figueroa-López P, Camacho-Casas MA, Félix-Fuentes JL, Chávez-Villalba G, and Rosas-Jáuregui IA. 2016. Biological effectiveness of several fungicides for control of karnal bunt (Tilletiaindica) of wheat, in the field. Annual Wheat Newsletter 62:28-31.

Fuentes-Dávila G, Figueroa-López P, Cortés-Jiménez JM, Félix-Valencia P, Camacho-Casas MA, Chávez-Villalba G, Félix-Fuentes JL, and Ortiz-Ávalos AA. 2013. Effect of the level of wheat seed infection with karnal bunt, on germination and tiller production. Annual Wheat Newsletter 59:45-48.

Fuentes-Dávila G, Prakash-Singh R, Rosas-Jáuregui IA, Ayón-Ibarra CA, Félix-Valencia P, Félix-Fuentes JL, and Camacho-Casas MA. 2018a. Evaluating advanced bread wheat lines for Karnal bunt resistance in the field during the 2012-2013 crop season. Annual Wheat Newsletter 64:25-30.

Fuentes-Dávila G, Prakash-Singh R, Rosas-Jáuregui IA, Ayón-Ibarra CA, Torres-Cruz MM, Félix-Valencia P, Félix-Fuentes JL, and Chávez-Villalba G. 2019. Evaluation of advanced bread wheat lines for Karnal bunt resistance in the field during the 2013-14 crop season. Annual Wheat Newsletter 65:40-44.

Fuentes-Dávila G, Prakash-Singh R, Rosas-Jáuregui IA, Ayón-Ibarra CA, Torres-Cruz MM, Félix-Valencia P, Félix-Fuentes JL, and Chávez-Villalba G. 2020. Evaluation of advanced bread wheat lines for Karnal bunt resistance in the field during the 2014-15 crop season. Annual Wheat Newsletter 66:58-62.

Fuentes-Dávila G., Prakash-Singh R, Rosas-Jáuregui IA, Félix-Fuentes JL, and Ayón-Ibarra CA. 2018b. Evaluation of bread wheat lines for resistance to karnal bunt. Global Advanced Research Journal of Agricultural Science 7(8):268-271.

Fuentes-Dávila G,Prakash-Singh R, Vega-Ochoa JA, Figueroa-López P, Camacho-Casas MA, Félix-Fuentes JL y Chávez-Villalba G. 2014. Evaluación de líneas elite de trigo harinero para resistencia al carbón parcial durante el ciclo 2013-14. pp. 383-388. Memorias del XVII Congreso Internacional de Ciencias Agrícolas. Octubre 9 y 10, 2014. Mexicali, Baja California, México. 622 p. 
Vol. 06, No. 05; 2021

ISSN: $2456-8643$

Fuentes-Davila G, and Rajaram S.1994. Sources of resistance to Tilletiaindica in wheat. Crop Prot. 13(1):20-24.

Fuentes-Davila G, Rajaram S, Pfeiffer WH, and Abdalla O. 1992. Results of artificial inoculation of the 4th Karnal Bunt Screening Nursery (KBSN). Annual Wheat Newsletter 38:157-162.

Fuentes-Davila G, Rajaram S, Pfeiffer WH, Abdalla O, Van-Ginkel M, Mujeeb-Kazi A, yRodríguez-Ramos R. 1993. Resultados de inoculaciones artificiales del 5o. vivero de selecciónpara resistencia a Tilletia indica Mitra. Revista Mexicana de Micología 9:57-65.

Fuentes-Dávila G, Rosas-Jáuregui IA, Ayón-Ibarra CA, Álvarez-Amado KD, Félix-Valencia P, and Félix-Fuentes JL. 2018c. Biological effectiveness of Opus, Folicur, Juwel, and Bemistop for control of Karnal bunt (Tilletiaindica) of wheat in the field. AnnualWheatNewsletter 64:30-33.

Fuentes-Dávila, G., and Singh, P.R. 2006. Evaluation of elite bread wheat lines and synthetic hexaploid wheat derivatives ( $T$. turgidum subsp. turgidum/Aegilopstauschii//T. aestivum subsp. aestivum) for resistance to Karnal bunt. Annual Wheat Newsletter 52:90-92.

Fuentes-Dávila G, Tapia-Ramos E, Toledo-Martínez JA y Figueroa-López P. 2005. Evaluación de efectividad biológica de folicur 250 EW (Tebuconazol) para el control del carbón parcial (Tilletia indica) del trigo (Triticumaestivum), en el valle del Yaqui, Sonora, México, durante el ciclo de cultivo 2003-2004. Resúmenes, XIII Congreso Latinoamericano de Fitopatología, III Taller de la Asociación Argentina de Fitopatólogos. 19-22 de Abril, 2005. Villa Carlos Paz, Córdoba, Argentina. Resumen HC-29, página 271. 640 p.

García E. 1988. Modificaciones al sistema de classificación climática de Köppen. Instituto de Geografía de la Universidad Nacional Autónoma de México. Serie Libros número 6. México, D.F. 90 p.

Krishna A, and Singh RA. 1982. Effect of physical factors and chemicals on the teliospore germination of Neovossiaindica. Indian Phytopathology 35(3):448-455.

Mitra M. 1931. A new bunt of wheat in India. Ann. Appl. Biol. 18:178-179.

Mitra M. 1935. Stinking smut (bunt) of wheat with a special reference to TilletiaindicaMitra. Indian J. Agric. Sci. 5:1-24.

Mujeeb-Kazi A, Fuentes-Davila G, Gul A, and Mirza JI. 2006. Karnal bunt rsistance in synthetic hexaploid wheats (SH) derived from durum wheat x Aegilopstauschii combinations and in some SH x bread wheat derivatives. Cereal ResearchCommunications 34(4):1199-1205.

Munjal RL. 1975. Status of Karnal bunt (Neovossiaindica) of wheat in Northern India during1968-1969 and 1969-1970. Indian Journal of Mycology and Plant Pathology 5(2):185-187. Rai RC, and Singh AA. 1978. A note on the viability of wheat seeds infected with Karnal bunt. Seed Res. 6:188-190.

Plamenov D, and Spetsov P. 2011. Synthetic hexaploid lines are valuable resources for biotic stress resistance in wheat improvement. Journal of Plant Pathology 93(2):251-262.

Rajaram S, Fuentes-Davila G, van Ginkel M, Getinet G, Camacho M, Montoya J, Amaya A, Peña J, He Zhong H, and Tinayou C. 1991. Breeding bread wheat resistance to Karnal bunt (Tilletiaindica). pp. 14-15. In: Update on Karnal Bunt Research in Mexico. Wheat Special Report No. 7. CIMMYT, Mexico, D.F.

Salazar-Huerta FJ, Figueroa-Lopez P, Smilanick, JL, and Fuentes-Davila G. 1997. Evaluation offoliar fungicides for control of Karnal bunt of wheat during 1986-1989 in northwestern Mexico.Revista Mexicana de Fitopatología 15:73-80. 
Vol. 06, No. 05; 2021

ISSN: 2456-8643

SARH. 1987. Cuarentena interior No. 16 contra el Carbón Parcial del trigo. Secretaría deAgricultura y Recursos Hidráulicos. Diario Oficial, (jueves) 12 de Marzo de 1987, México.

Singh DV. 1980. A note on the effect of Karnal bunt infection on the vigour of wheat seed. Seed Res. 8:81-82.

Singh DV, Agarwal R, Shrestha KJ, Thapa RB, and Dubin HJ. 1989. First report of Tilletiaindica on wheat in Nepal. Plant Disease 73:273.

Singh DV, Joshi LM, and Srivastava KD. 1986. Varietal suceptibility and spread of Karnal Buntof wheat in India. Rachis 5:40-42.

Singh A, Singh KP, and Tewari AN. 1988. Salient findings of Karnal bunt research at Pantnagar.Department of Plant Pathology, G.B. Pant University of Agriculture and Technology, Pantnagar263 145.

Smilanick JL, Hoffmann JA, and Royer MH. 1985. Effect of temperature, pH, light, anddesiccation on teliospore germination of Tilletiaindica. Phytopathology 75:1428-1431.

Smilanick JL, Hoffmann JA, Secrest LR, and Wiese K.1988. Evaluation of chemical andphysical treatment to prevent germination of Tilletiaindicateliospores. Plant Disease 72:46-51.

Torarbi M, Mardoukhi V, and Jalaiani N. 1996. First report on the occurrence of partial bunt on wheat in the southern parts of Iran. Seed and Plant 12:8-9.

Villareal, R. L., G. Fuentes-Davila, A. Mujeeb-Kazi and S. Rajaram. 1995. Inheritance of resistance to Tilletiaindica (Mitra) in synthetic hexaploid wheat x Triticumaestivum crosses. Plant Breeding 114:547-548.

Warham EJ, Mujeeb-Kazi A, and Rosas V. 1986. Karnal bunt (Tilletiaindica) resistance of Aegilops species and their practical utilization for Triticumaestivum improvement. Canadian Journal of Plant Pathology 8:65-70.

Zhang Z, Lange L, and Mathur SB. 1984. Teliospore survival and plant quarantine significance of Tilletiaindica (causal agent of Karnal bunt) particularly in relation to China. Eur. Plant Prot. Bull. 14:119-128. 